\title{
Composição físico-química de carcaças de bezerros holandeses alimentados após o desaleitamento com silagem de grãos úmidos ou grãos secos de milho ou sorgo ${ }^{1}$
}

\section{Gercílio Alves de Almeida Júnior ${ }^{2}$, Ciniro Costa ${ }^{3}$, Sebastião Marcos Ribeiro de Carvalho ${ }^{4}$, Pedro Persichetti Júnior ${ }^{5}$, Amanda Panichi ${ }^{5}$}

\author{
1 Projeto financiado pela Unimar - Universidade de Marília e UNESP. \\ ${ }^{2}$ Departamento de Zootecnia da Faculdade de Ciências Agrárias - Universidade de Marília, CEP: 17525-902, Marília, SP. \\ ${ }^{3}$ Departamento de Melhoramento e Nutrição Animal da FMVZ-UNESP, Botucatu, SP. \\ 4 Programa de Pós-Graduação em Agronomia da Faculdade de Ciências Agrárias da Universidade de Marília. \\ ${ }^{5}$ Curso de Graduação em Zootecnia - Unimar.
}

RESUMO - Avaliou-se a composição físico-química de carcaças de bezerros após desaleitamento até o abate com silagem de grãos úmidos ou grãos secos de milho ou sorgo para a produção de vitelos de carne rosa. Trinta bezerros holandeses foram distribuídos em delineamento em blocos casualizados, com cinco blocos e seis tratamentos, e alimentados com seis rações com teores similares de proteína (18,5\% PB) e de energia (3,2 Mcal EM/kg de MS), formuladas com: milho seco moído (MM); silagem de grãos úmidos de milho (SGUM); sorgo seco com tanino moído (SCTM); silagem de grãos úmidos inteiros de sorgo com tanino (SGUISCT); sorgo seco sem tanino moído; e silagem de grãos úmidos inteiros de sorgo sem tanino (SGUISST). Após o resfriamento, foram tomados nas meias-carcaças esquerdas os cortes da seção H\&H para estimativa da composição tecidual da carcaça e os cortes no Longissimus dorsi à altura da 12a e 13a costelas para determinação da área de olho-de-lombo (AOL), da espessura de gordura subcutânea (EGS), da força de cisalhamento (FC) e da composição química. Não houve efeito da composição das rações concentradas sobre a composição física e a relação entre tecidos na seção H\&H, bem como para AOL, EGS e FC. A ração concentrada SGUM resultou em maiores teores de EE no Longissimus dorsi, mas não diferiu das rações SCTM e SSTM. A ração concentrada SGUM gerou maior deposição de gordura muscular em comparação à MM, no entanto, as rações SGUISCT e SGUISST não aumentaram essa deposição em comparação ao fornecimento dos grãos secos moídos. Todos os alimentos avaliados podem ser usados em rações concentradas para bezerros após o aleitamento, pois não comprometem a composições física e química da carcaça e conferem resultados similares.

Palavras-chave: gordura muscular, qualidade de carne, vitelos de carne rosa

\section{Physical and chemical carcasses composition of Holstein calves fed after weaning with high moisture grains silage or dry ground grains of corn or sorghum}

\footnotetext{
ABSTRACT - The physical and chemical carcasses composition of calves fed after weaning until slaughter with high moisture grains silage or dry ground grains of corn or sorghum was evaluated, for production of pink meat veal. Thirty Holstein calves were alloted to a complete randomized blocks experimental design with five blocks and six concentrate rations with similar contents of protein (18.5\% CP) and energy (3.2 Mcal ME/kg DM), formulated with dry ground corn (GC), high moisture corn silage (HMCS), dry ground sorghum with tannin (GSWT), high moisture whole sorghum with tannin silage (HMWSWTS), dry ground sorghum without tannin (GSWTT) or high moisture whole sorghum without tannin silage (HMWSWTTS). After cooling, the H\&H sections of left half-carcasses were selected to estimate the tissue of carcass composition and the cuts in the Longissimus dorsi at $12^{\text {th }}$ and $13^{\text {th }}$ ribs to determine the rib eye area (REA), subcutaneous fat thickness (SFT), shear force (SF) and chemical composition. No treatment effects were observed on physical composition and relation among the tissues of H\&H section and as for REA, SFT and SF. The concentrate ration HMCS showed higher content of EE in the Longissimus dorsi, but did not differ from GSWT and GSWTT. The concentrate ration HMCS promoted higher muscular fat deposition as compared to GC, but the concentrate rations HMWSWTS and HMWSWTTS did not show the same result as compared to the dry ground grains fed. All diets can be used in veal feedlot calves without effect on their carcasses tissue composition and meat tenderness. All evaluated feeds could be used in the concentrate rations for calves after weaning, because they do not impair physical and chemical carcass composition and confer similar results.
}

Key Words: meat quality, muscular fat, non-special-fed veal 


\section{Introdução}

O Brasil possui um plantel estimado em 20,5 milhões de vacas ordenhadas, produzindo anualmente apenas 25 bilhões de kg de leite (Embrapa, 2006). Essa baixa produtividade por animal faz com que o país produza basicamente apenas o montante que a população nacional consome, de modo que muitas vezes o mercado é abastecido com produtos importados. Outro aspecto relevante é que a pecuária de leite é considerada atividade de baixa rentabilidade por apresentar altos custos de produção em relação aos preços de venda, baixa produtividade por animal e por área e pequenos volumes produzidos individualmente pelas unidades fundiárias produtoras, em sua maioria familiares.

Nesse aspecto, deve-se considerar que a venda de animais excedentes ou de descarte é a segunda grande receita de qualquer propriedade leiteira e, desse plantel estimado de vacas, pode-se esperar produção anual de 5,5 milhões de bezerros, que poderiam ser criados em sistemas diferenciados de produção para elevar a receita dessas propriedades e aumentar a produção de carne no Brasil. Esses machos leiteiros apresentam pouca competitividade para a produção comercial de carne nos sistemas tradicionais de produção de animais em pastejo no país, independentemente de serem provenientes de cruzamentos com raças zebuínas ou de plantéis leiteiros especializados com raças européias, que, por serem animais que não se adaptam aos sistemas tradicionais de criação extensiva, requerem criação intensiva ou semi-intensiva que aumenta sobremaneira os custos de produção do animal e inviabiliza sua venda no mercado de bovinos de ciclo longo. Nessa perspectiva, torna-se difícil criar no país condições técnicas, competitivas, econômicas e culturais favoráveis à criação desses machos leiteiros para produção de carne.

Uma das alternativas para viabilizar economicamente a criação desses animais, diferenciar sua carne da carne de bovinos adultos e agregar valor é a produção de vitelos. A carne de vitelos corresponde a grande parte da carne bovina consumida em muitos países europeus, norte-americanos e asiáticos, importadores tradicionais de carne in natura ou industrializada brasileira. No Brasil, a carne de vitelos pode também se tornar uma opção a mais de oferta, tanto para o consumidor doméstico quanto para o mercado externo, por ser muito macia e possuir menor teor de gordura, o que a classifica como carne light, nobre e saudável.

Os vitelos podem ser classificados como de carne branca, animais criados com dietas líquidas baseadas em sucedâneos de leite, ou de carne rosa, alimentados com concentrados e volumosos. A criação de vitelos de carne rosa não gera a propaganda negativa que permeia a criação do vitelo tradicional de carne branca, uma vez que o sistema de criação permite ao animal exercer seus comportamentos naturais de locomoção, exposição ao sol, ócio, interatividade, ingestão e ruminação de alimentos. Além disso, o animal recebe uma dieta totalmente balanceada e não uma dieta líquida ferropriva como no sistema de produção de vitelos de carne branca, no qual os animais são usualmente confinados em baias individuais.

Visando obter alternativas de produção que viabilizem economicamente a criação desses animais sem comprometimento de seu desempenho e da qualidade de carne, é importante a avaliação de alimentos e formas de processamento de grãos que tenham menores custos em comparação aos do milho seco moído na alimentação desses animais.

Assim, este trabalho foi realizado com o objetivo de avaliar os efeitos da utilização de milho ou sorgo sob as formas de silagem de grãos úmidos ou grãos secos moídos sobre a composição física e química de carcaças e a maciez da carne de bezerros holandeses abatidos como vitelos de carne rosa aos $170 \mathrm{~kg}$ PV.

\section{Material e Métodos}

O experimento foi conduzido no Setor de Bovinocultura de Leite da Universidade de Marília, Marília - SP, onde foram avaliadas seis rações concentradas com teores similares de proteína (18,5\% PB na MS) e energia (3,2 Mcal EM/kg de MS), contendo: milho seco moído (MM); silagem de grãos úmidos de milho (SGUM); sorgo seco com tanino moído (SCTM); silagem de grãos úmidos inteiros de sorgo com tanino (SGUISCT); sorgo seco sem tanino moído (SSTM); ou silagem de grãos úmidos inteiros de sorgo sem tanino (SGUISST).

O milho usado na silagem de grãos úmidos foi o semidentado, C 333B, e o milho usado para moagem como grãos secos foi do tipo duro (flint), adquirido no comércio local. O sorgo com tanino (0,95\% de tanino) usado como grãos secos moídos ou silagem de grãos úmidos foi o BR 701 e o sorgo sem tanino (0,37\% de tanino), usado também como grãos secos moídos ou silagem de grãos úmidos, foi o AG 1018.

As dietas foram estabelecidas com base nas exigências preconizadas pelo NRC (2001) e foram compostas de cada uma das seis rações concentradas (Tabela 1), fornecidas em 1,1\% PV MS, além de caroço de algodão (1,1\% PV MS) e silagem de milho (1,5\% PV MS). Os animais foram alimentados duas vezes ao dia com $70 \%$ da dieta oferecida no período da tarde (15h30) e 30\% oferecida no período da manhã (9 h). As quantidades ofertadas foram ajustadas 
Tabela 1 - Composição das rações concentradas (\%MS)

\begin{tabular}{|c|c|c|c|c|c|c|}
\hline Ingrediente & \multicolumn{6}{|c|}{ Ração concentrada } \\
\hline Milho seco moído & 78,50 & & & & & \\
\hline Sorgo seco com tanino moído & & & 80,50 & & & \\
\hline SGUI $^{2}$ de sorgo com tanino & & & & 79,00 & & \\
\hline Sorgo seco sem tanino moído & & & & & 81,40 & \\
\hline Uréia & 1,50 & 1,50 & 1,50 & 1,50 & 1,50 & 1,50 \\
\hline Núcleo mineral vitamínico ${ }^{3}$ & 7,00 & 7,00 & 7,00 & 7,00 & 7,00 & 7,00 \\
\hline
\end{tabular}

1 Silagem de grãos úmidos.

2 Silagem de grãos úmidos inteiros.

${ }^{3}$ Núcleo Bovino Nutron Bezerro Cromo®: $25 \%$ de cálcio; $6,5 \%$ de fósforo; $4,9 \%$ de sódio; 875 mg/kg de monensina sódica e 25 ppm de cromo.

MM - milho seco moído; SGUM - silagem de grãos úmidos de milho; SCTM - sorgo seco com tanino moído; SGUISCT - silagem de grãos úmidos inteiros de sorgo com tanino; SSTM - sorgo seco sem tanino moído; SGUISST - silagem de grãos úmidos inteiros de sorgo sem tanino.

após as pesagens, realizadas a cada 28 dias, de modo que as sobras se mantivessem em $10 \%$ da matéria original ofertada nas últimas 24 horas.

Foram utilizados 30 bezerros holandeses (HPB) PO e PC com 96 dias de idade 96 e 79,3 kg PV, distribuídos nos seis tratamentos totalizando cinco animais por tratamento. Os animais foram distribuídos em lotes de acordo com o tratamento, em piquetes com 13,0 × 19,0 m, dotados de cochos cobertos e bebedouros plásticos abastecidos diariamente.

Os animais não foram castrados nem mochados e foram vacinados contra clostridioses e febre aftosa de acordo com o calendário oficial. O controle de infecções parasitárias foi feito por meio de aplicações de ivermectina a $1 \%$ (Iverbion ${ }^{\circledR}$ ) em todos os animais no dia de entrada nesta fase do experimento. Novas aplicações foram feitas a cada pesagem e, sempre que necessário, também foram feitos banhos carrapaticidas.

À medida que os animais atingiram o peso pré-estabelecido para o abate (170 $\pm 10 \mathrm{~kg} P V)$, foram submetidos a jejum de alimentos sólidos por 16 horas, novamente pesados e, em seguida, foram abatidos. Após o abate, a esfola, a evisceração e a limpeza, as carcaças foram seccionadas, mensuradas, pesadas, identificadas e embaladas em sacos plásticos para serem resfriadas em câmara de refrigeração por 24 horas a $5^{\circ} \mathrm{C}$.

Depois de resfriadas, as meias-carcaças foram desembaladas e novamente pesadas. Nas metades esquerdas, foram retirados e congelados a $-20^{\circ} \mathrm{C}$ os cortes transversais inerentes à região da $9 \underline{a}, 10^{\underline{a}}$ e $11 \underline{\underline{a}}$ costelas para se obter a seção $H \& H$ para posterior dissecação e determinação das proporções de ossos $(\mathrm{Y}=5,52+0,57 \mathrm{X})$, músculos $(\mathrm{Y}=16,08+0,80 \mathrm{X})$ e gordura $(\mathrm{Y}=3,54+0,80 \mathrm{X})$, de modo que $\mathrm{X}$ correpondeu ao percentual de cada componente na dissecação da seção H\&H (Hankins \& Howe, 1946).
A partir dos pesos obtidos para cada tecido, foram estabelecidas também as relações entre músculos e ossos, gordura e ossos, tecido mole (músculo + gordura) e ossos e, por último, a relação entre gordura e músculos. As dissecações foram realizadas em laboratório no Departamento de Zootecnia da Faculdade de Ciências Agrárias da Universidade de Marília, Unimar.

À altura da $12^{\mathrm{a}}$ costela, foram medidas a área do músculo Longissimus dorsi, traçando seu contorno em transparência para posterior mensuração com programa AutoCAD (Release 14.0, versão R14.0.0, copyright 1982 1997 by Autodesk, Inc.), e a espessura de gordura subcutânea, tomada com paquímetro.

Os cortes com $\pm 1,5 \mathrm{~cm}$ de espessura da região proximal da $12^{\mathrm{a}}$ costela foram congelados $\left(-20^{\circ} \mathrm{C}\right)$ e utilizados para determinação de composição química do Longissimus dorsi, no Laboratório de Carnes do Departamento de Gestão e Tecnologia Agroindustrial, da Faculdade de Ciências Agronômicas da Universidade Estadual Paulista - UNESP, Botucatu. No laboratório, foram feitas as análises para determinação dos teores de umidade pelo método 950.46 da AOAC (1990) e proteína pelo método de Kjeldahlmicro (AOAC, 1990), item 928.080, para determinação do nitrogênio total. A concentração de PB foi calculada multiplicando-se os teores de $\mathrm{N}$ total pelo fator 6,25 e o EE segundo AOAC (1990).

Realizaram-se também cortes de 2,54 cm de espessura na região entre a $12^{\underline{a}}$ e a $13^{\underline{a}}$ costelas, que foram congelados a $-20^{\circ} \mathrm{C}$ para determinação da força de cisalhamento (shear force) segundo Wheeler et al. (1997), por meio de determinação pelo Warner-Bratzler Shear Force (5-Speed Drillpress, Model nZJ4110, Chuck 1²”, Spindle J2513, Motor 1/3 HP).

As análises objetivas para determinação da maciez das carnes foram realizadas no Laboratório de Análise de Carnes do Departamento de Melhoramento e Nutrição 
Animal da Faculdade de Medicina Veterinária e Zootecnia da Universidade Estadual Paulista - UNESP, Botucatu. A determinação das perdas por cocção foi feita pela pesagem das bandejas, grelhas e amostras antes e após o cozimento, realizado em forno elétrico a $200^{\circ} \mathrm{C}$ até que as amostras atingissem temperatura interna de $70^{\circ} \mathrm{C}$. As perdas totais por cocção foram determinadas pela soma das perdas por evaporação e das perdas por gotejamento. Para o cálculo, foram subtraídos do peso da amostra crua o peso do resíduo na bandeja após cozimento (gotejamento) e o peso da amostra assada. O valor obtido foi dividido pelo peso da amostra crua e multiplicado por 100.

O delineamento experimental adotado foi o de blocos casualizados, com cinco blocos e seis tratamentos com cinco repetições por tratamentos, e a comparação entre os grupos foi realizada por meio de análise de variância com um fator, complementada pelo teste Tukey, utilizando-se para cálculos o Programa Computacional SANEST (IAC, 1992).

Adotou-se o delineamento em blocos casualizados porque, na primeira fase da criação (pré-desaleitamento), os animais foram distribuídos de acordo com a ordem de entrada em abrigos individuais dispostos em blocos e os efeitos desse delineamento foram mantidos neste último período da criação.

\section{Resultados e Discussão}

Não houve efeito $(\mathrm{P}>0,05)$ da composição das rações sobre nenhum dos tecidos componentes da carcaça e nenhuma das relações avaliadas entre esses tecidos (Tabela 2).

Signoretti et al. (1999), avaliando dietas para bezerros holandeses abatidos aos $190 \mathrm{~kg}$ PV, obtiveram valores similares aos deste experimento com médias de 59,60\% para músculos, $21,80 \%$ para gordura e $18,51 \%$ para ossos. O percentual de gordura obtido por esses autores foi maior, talvez por terem trabalhado com animais mais pesados e usado dietas de alto grão, o que favorece a deposição de tecido adiposo. As relações também foram bem similares, com médias de 3,24 para músculo : osso, 1,19 para gordura : osso, 4,42 para tecido mole : osso e 0,37 para gordura : músculo.

Rodrigues Filho et al. (2003) abateram machos holandeses com pesos pré-fixados de $215 \mathrm{~kg}$ PV alimentados com diferentes dietas e observaram proporções médias de $64,78 \%$ de músculos, 18,15\% de gordura e 17,28\% de ossos e nenhuma diferença entre tratamentos. Carvalho et al. (2003), avaliando a composição tecidual da carcaça de bezerros holandeses abatidos com peso vivo médio de $87,0 \mathrm{~kg}$, encontraram percentuais de tecido muscular, tecido adiposo e tecido ósseo determinados na secção H\&H de 55,98; 7,2; e 31,92\%, respectivamente.

Signoretti et al. (1999), afirmaram que a proporção de ossos na carcaça apresenta a menor variação percentual e diminui lentamente à medida que o peso total aumenta. Os músculos representam alta porcentagem do peso total ao nascimento, que aumenta ligeiramente e decresce à medida que se inicia a fase de deposição de gordura.

Em animais abatidos com pesos pré-fixados, eventuais diferenças de composição tecidual são pouco encontradas e, uma vez que neste experimento o peso ao abate foi préfixado (170 $\pm 10 \mathrm{~kg}$ PV), não houve influência da maturidade fisiológica dos animais sobre as deposições de tecidos. Um aspecto importante é que animais de raças leiteiras normalmente apresentam menor musculosidade em comparação aos de raças de corte, portanto, o teor de gordura oscila de acordo com o tamanho corporal (frame size) e o grau de acabamento menor variação percentual.

Nas avaliações de áreas de olho-de-lombo (AOL), medidas na seç̧ão transversal do Longissimus dorsi entre a 12 e $13^{\mathfrak{a}}$ costelas, não foram identificados efeitos

Tabela 2 - Composição física da secção H\&H e relações entre tecidos

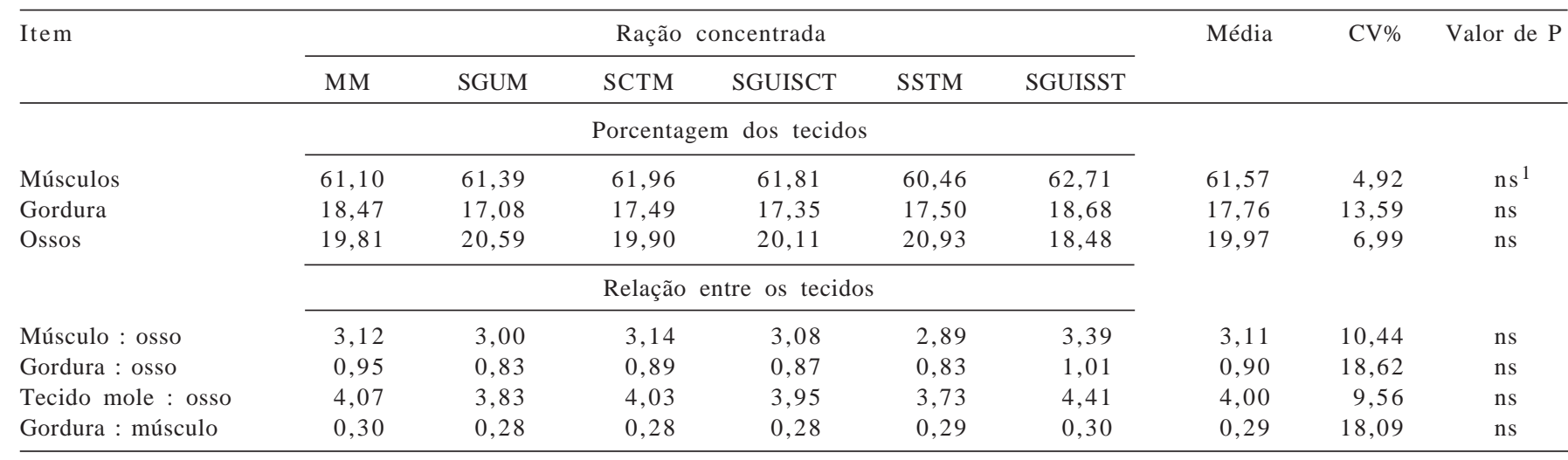

MM - milho seco moído; SGUM - silagem de grãos úmidos de milho; SCTM - sorgo seco com tanino moído; SGUISCT - silagem de grãos úmidos inteiros de sorgo com tanino; SSTM - sorgo seco sem tanino moído; SGUISST - silagem de grãos úmidos inteiros de sorgo sem tanino.

${ }^{1}$ Não-significativo - $P>0,05$. 
de tratamento $(\mathrm{P}>0,05)$ e as medidas apresentaram o valor médio de 36,68 cm² (Tabela 3). Rocha et al. (1999) obtiveram AOL de $34,3 \mathrm{~cm}^{2}$ em machos holandeses abatidos aos $202 \mathrm{~kg}$ PV.

Ribeiro et al. (2001) obtiveram medidas linearmente crescentes $(\mathrm{P}<0,05)$ de AOL em animais holandeses abatidos aos $200 \mathrm{~kg}$ PV com dietas contendo de 45\% (AOL = $\left.29,60 \mathrm{~cm}^{2}\right)$ a até $90 \%$ de concentrados $\left(\mathrm{AOL}=37,38 \mathrm{~cm}^{2}\right)$ e observaram que, como os animais foram abatidos em plena fase de crescimento corporal, a energia adicional provida pelas dietas de alto grão foi utilizada prioritariamente para a síntese muscular, uma vez que ao abate os animais apresentavam pouca ou nenhuma gordura subcutânea. Neste trabalho, essa tendência não foi observada, provavelmente porque as dietas apresentaram teores semelhantes de energia e as quantidades ofertadas de concentrados também foram similares entre os tratamentos.

Não houve efeito das rações sobre a espessura de gordura subcutânea, que apresentou valor médio de 1,15 mm. Rodrigues Filho et al. (2003) avaliaram as carcaças de bezerros holandeses abatidos com $45 \mathrm{~kg}$ a mais que os animais deste experimento (215 kg PV) e verificaram que a espessura de gordura de cobertura nos animais alimentados com dieta de alto grão ( $75 \%$ concentrados) foi maior $(\mathrm{P}<0,05) 4,05 \mathrm{~mm}$ que naqueles alimentados com dietas com menor concentração energética $(2,78 \mathrm{~mm})$.

$\mathrm{Na}$ análise desses resultados, verificou-se que, nessa faixa de peso, dependendo da densidade energética da dieta, é possível obter carcaças com a cobertura mínima desejável (3,0 mm) para o resfriamento convencional adotado pelos frigoríficos nacionais.

A espessura de gordura é importante para proteger as carcaças de efeitos prejudiciais do resfriamento intenso e brusco ao qual as carcaças são submetidas nos frigoríficos. O resfriamento pode promover o encurtamento das fibras musculares, a desidratação, o ressecamento e o escurecimento da carne, depreciando-a. No entanto, vitelos são animais desprovidos de gordura, um dos atributos diferenciais dessa carne considerada magra.

Na realidade, carcaças com maior grau de acabamento talvez sejam interessantes apenas para o mercado de carnes para churrasco, por questões de hábito de consumo do brasileiro. Segundo alguns autores, a carne de vitelo, por não ter usualmente essa cobertura mínima de gordura, não deveria ser congelada sem processamento, devendo ser, a princípio, apenas resfriada e comercializada o mais rápido possível (Campos et al., 1996).

Nas determinações de maciez das carnes (shear force), não foram encontrados efeitos das rações $(\mathrm{P}>0,05)$ sobre a força de cisalhamento, que apresentou média de 3,07 kgf. Esse valor denota elevada maciez da carne dos vitelos, uma vez que valores em torno de 5,5 kgf para carne de bovinos são considerados indicativos de elevada maciez. Vaz \& Restle (2005), avaliando carcaças de novilhos Hereford alimentados com silagem de milho e abatidos com $446 \mathrm{~kg}$ PV, encontraram força de cisalhamento de 7,33 kgf. Esses resultados indicam que bezerros holandeses abatidos como vitelos de carne rosa aos $170 \mathrm{~kg}$ PV produzem carne muito macia. Considerando que a maciez é a característica organoléptica mais avaliada pelo consumidor (Costa et al., 2002), esse atributo pode representar grande importância no aspecto de valorização econômica e comercialização dessa carne.

As perdas totais por cocção não diferiram entre os tratamentos e apresentaram valor médio de 22,92\%. Moura et al. (1999) encontraram perdas totais médias de 28,13\% para carnes no primeiro dia de maturação, 27,08\% para carnes com maturação de 7 dias e 26,7\% com maturação de 14 dias. Vaz \& Restle (2005), preparando amostras de carne de novilhos Hereford para determinação da força de cisalhamento, verificaram perdas totais por cocção de 32,4\%.

As perdas por cocção são atribuídas principalmente à perda de água, gordura fundida, componentes nitrogenados e minerais (Lawrie, 1981). Portanto, é importante determinar

Tabela 3 - Características de carcaça avaliadas no Longissimus dorsi

\begin{tabular}{|c|c|c|c|c|c|c|c|c|c|}
\hline Item & \multicolumn{6}{|c|}{ Ração concentrada } & Média & $\mathrm{CV} \%$ & Valor de $\mathrm{P}$ \\
\hline Área de olho-de-lombo $\left(\mathrm{cm}^{2}\right)$ & 38,60 & 34,75 & 38,00 & 35,13 & 38,78 & 34,79 & 36,68 & 16,46 & $\mathrm{~ns}^{1}$ \\
\hline Força de cisalhamento (kgf) & 2,92 & 2,73 & 3,01 & 3,35 & 3,58 & 2,80 & 3,07 & 25,19 & ns \\
\hline Perdas totais por cocção (\%) & 24,57 & 22,88 & 20,02 & 26,47 & 22,48 & 22,69 & 22,92 & 22,89 & ns \\
\hline Umidade (\%) & 77,80 & 77,93 & 77,10 & 77,45 & 77,32 & 77,94 & 77,59 & 0,69 & ns \\
\hline
\end{tabular}

MM - milho seco moído; SGUM - silagem de grãos úmidos de milho; SCTM - sorgo seco com tanino moído; SGUISCT - silagem de grãos úmidos inteiros de sorgo com tanino; SSTM - sorgo seco sem tanino moído; SGUISST - silagem de grãos úmidos inteiros de sorgo sem tanino.

Não significativo - $\mathrm{P}>0,05$; *Médias, na linha, seguidas de letras diferentes, diferem $(\mathrm{P}<0,05)$ pelo teste Tukey.

*Médias, na linha, seguidas de letras diferentes, diferem entre si $(P<0,05)$ pelo teste Friedman. 
a magnitude dessas perdas, pois essas perdas estão associadas à suculência da carne durante a degustação. Costa et al. (2002) obtiveram correlação negativa $(r=-0,34 ; P=0,0965)$ entre essas duas variáveis, indicando que aumentos na perda de líquidos representam redução na suculência durante a degustação.

As perdas por cocção neste trabalho foram bem menores que as obtidas nesses trabalhos, indicando mais um aspecto positivo quanto à qualidade da carne de vitelos. Um aspecto que pode explicar essas menores perdas por cocção foi destacado por Vaz et al. (2001), ao afirmarem que as perdas de líquidos por cocção tendem a ser menores na carne de animais não-castrados. Esses autores encontraram perdas totais por cocção de 30,10\% em novilhos castrados e 25,45\% em novilhos não-castrados. Como os bezerros utilizados neste experimento não foram castrados, essa hipótese pode ser considerada. No entanto, outro aspecto que ressaltado por Costa et al. (2002) é que aumentos nas perdas por cocção são comuns em maiores pesos de abate, tendência observada também neste trabalho, no qual os animais foram abatidos com pesos bem mais baixos.

Os teores de umidade (77,59\%) e proteína (20,20\%) no Longissimus dorsi não foram influenciados $(\mathrm{P}>0,05)$ pelas rações (Tabela 3). Cervieri etal. (2001) avaliaram os efeitos de dietas com diferentes degradabilidades da fração protéica em novilhos Brangus não-castrados abatidos aos 432 kg PV e não encontraram efeitos das rações sobre a composição química da carne dos animais. Esses autores obtiveram valores médios de 75,12\% de umidade, 18,37\% de proteína e 1,83\% de EE.

Vaz et al. (2001) encontraram para esses mesmos parâmetros em novilhos castrados abatidos aos $399 \mathrm{~kg}$ PV valores de 70,78; 26,34 e 2,88\%, respectivamente. Em novilhos não-castrados abatidos aos $425 \mathrm{~kg}$ PV, esses autores obtiveram 71,94\% de umidade, 26,33\% de proteína e $1,73 \%$ de EE.

O percentual de EE no Longissimus dorsi foi maior $(\mathrm{P}<0,05)$ nos animais alimentados com silagem de grãos úmidos de milho em comparação àqueles alimentados com milho seco moído e silagens de grãos úmidos inteiros de sorgo com ou sem tanino, mas não diferiu $(\mathrm{P}>0,05)$ do percentual obtido nos animais alimentados com sorgos com ou sem tanino na forma de grãos secos moídos. O sorgo seco com tanino moído também conferiu maior $(\mathrm{P}<0,05)$ teor de EE em comparação ao milho seco moído e à silagem de grãos úmidos de sorgo sem tanino.

De acordo com Costa et al. (2002), o EE corresponde aos lipídeos depositados entre as células e no interior das células e aumentos na sua porcentagem são associados a aumentos de palatabilidade e suculência da carne. Esses autores avaliaram carcaças de bovinos Red Angus jovens em confinamento e observaram alta correlação do EE no músculo Longissimus dorsi com o teor de gordura intramuscular ou marmoreio $(\mathrm{r}=0,42 ; \mathrm{P}=0,04)$ e o teor de gordura total na carcaça $(r=0,58 ; \mathrm{P}=0,0026)$.

Resultados de diversas pesquisas comprovaram que alimentos que proporcionem maior digestão ruminal do amido, como as silagens de grãos úmidos, tendem a conferir maior deposição de gordura na carcaça e menor deposição nas vísceras (Owens et al., 1986; Taniguchi et al., 1995). Alimentos que apresentam maior fermentação ruminal aumentam a produção de AGV e, no caso das silagens de grãos úmidos, a fermentação do amido aumenta a produção de propionato, que, após absorção ruminal, pode ser convertido em glicose no fígado.

Huntington (1997) estimou que $44 \%$ das necessidades de glicose de animais alimentados com dietas com maior proporção de concentrados provêm da absorção de AGV no rúmen (principalmente propionato), 33\% provêm da absorção pós-ruminal de glicose e $23 \%$ provêm de outras fontes carbônicas como aminoácidos e sua subseqüente conversão em glicose no fígado. Taniguchi et al. (1995) observaram que a absorção líquida de glicose no intestino avaliada na veia porta seria praticamente nula, ou seja, os carboidratos absorvidos no intestino seriam prioritariamente utilizados no metabolismo energético dos tecidos locais e deposição de gordura visceral.

Smith \& Crouse (1984) demonstraram que a glicose disponível à circulação sanguínea periférica seria responsável por 50 a 75\% das unidades acetil para a lipogênese nos depósitos de gordura intramuscular e 1 a $10 \%$ das unidades de acetil para a lipogênese nos depósitos de gordura subcutânea.

Fahey Jr. \& Berger (1988) destacaram também a importância do acetato gerado na fermentação ruminal como precursor de ácidos graxos para a formação do tecido adiposo. Aproximadamente $80 \%$ do acetato que chega ao fígado escapa à oxidação e passa à circulação periférica, onde é oxidado via ciclo do ácido tricarboxílico ou usado para a síntese de ácidos graxos nos tecidos periféricos.

Assim, ao maximizar a digestão ruminal dos alimentos, o maior aporte decorrente de AGV favorece a deposição de tecido adiposo na carcaça bovina e a menor deposição de tecido adiposo nas vísceras. Neste experimento, os resultados obtidos com a silagem de grãos úmidos de milho confirmaram essa expectativa de maior deposição muscular de gordura em relação ao milho moído.

Contudo, o mesmo comportamento não foi observado no sorgo, o que está relacionado ao fato de as silagens de grãos úmidos de sorgo terem sido feitas com grãos inteiros, 
não moídos. Como o tegumento que reveste o grão é muito resistente ao ataque enzimático da flora ruminal e do próprio organismo animal, é provável que a digestibilidade do amido no endosperma tenha sido menor nesses tratamentos, conferindo menor aporte de AGV em comparação aos sorgos secos moídos.

\section{Conclusões}

O sorgo com ou sem tanino, nas formas de grãos secos moídos ou de silagem de grãos úmidos, e a silagem de grãos úmidos de milho podem ser usados em rações para bezerros holandeses para produção de vitelos de carne rosa, pois não alteram a composição tecidual das carcaças nem a maciez da carne e conferem os mesmos resultados obtidos com o milho seco moído. Em comparação ao milho seco moído, a silagem de grãos úmidos de milho resulta em maior deposição de gordura no Longissimus dorsi, no entanto, as silagens de grãos úmidos inteiros de sorgo com ou sem tanino, comparativamente aos grãos secos moídos, não aumentaram esses teores.

\section{Literatura Citada}

ASSOCIATION OF OFFICIAL ANALYTICAL CHEMISTS AOAC. Official methods of analysis. 15.ed. Virginia, Washington: Arlington, 1990. 1298p.

CAMPOS, O.F.; LIZIEIRE, R.S.; SPALLA, R.G. et al. Experimento do CNPGL/Embrapa com abate de machinhos da raça holandesa aos 6 meses de idade apresenta bons resultados. Gado Holandês, v.451, p.36-45, 1996.

CARVALHO, P.A.; SANCHEZ, L.M.B.; VELHO, J.P. et al. Características quantitativas, composição física tecidual e regional da carcaça de bezerros machos de origem leiteira ao nascimento, 50 e 110 dias de idade. Revista Brasileira de Zootecnia, v.32, n.6, p.1476-1483, 2003.

CERVIERI, R.C.; ARRIGONI, M.B.; OLIVEIRA, H.N. et al. Desempenho e características de carcaça de bezerros confinados recebendo dietas com diferentes degradabilidades da fração protéica. Revista Brasileira de Zootecnia, v.30, n.5, p.15901599, 2001

COSTA, E.C.; RESTLE, J.; BRONDANI, I.L. et al. Composição física da carcaça, qualidade da carne e conteúdo de colesterol no músculo Longissimus dorsi de novilhos red angus superprecoces, terminados em confinamento e abatidos com diferentes pesos. Revista Brasileira de Zootecnia, v.31, n.1, p.417-428, 2002.

EMPRESA BRASILEIRA DE PESQUISA AGROPECUÁRIA EMBRAPA [2006]. Produção de leite, vacas ordenhadas e produtividade em países selecionados no ano de 2005. Disponível em: <http://www.cnpgl.embrapa.br/producao/ dados 2002/producao/tabela 02.19.php> Acesso em: 23.12. 2006.
FAHEY JR., G.C.; BERGER, L.L. Los carbohidratos en lla nutricion de los rumiantes. In: $\mathrm{CHURCH}$, C.D. (Ed.) El rumiante: fisiologia digestiva y nutrición. Zaragoza: Acribia, 1988. p.305-337.

HANKINS, O.G.; HOWE, P.E. Estimation of the composition of beef carcasses and cuts. Washington, D.C.: USDA, 1946. 20p (Technical Bulletin, 926).

HUNTINGTON, G.B. Starch utilization by ruminants: from basics to the bunk. Journal of Animal Science, v.75, n.3, p.852-867, 1997.

INSTITUTO AGRONÔMICO DE CAMPINAS - IAC. SANEST (Sistema de Análise Estatística). Campinas: 1992. (CD-ROM).

LAWRIE, R. Developments in meat science. London: Elsevier Applied Science, 1981. 342p.

MOURA, A.C.; LUCHIARI FILHO, A.; NARDON, R.F. et al. Efeitos da injeção de cloreto de cálcio pós-morte e tempo de maturação no amaciamento e nas perdas por cozimento do músculo Longissimus dorsi de animais Bos indicus e Bos taurus selecionados para ganho de peso. Revista Brasileira de Zootecnia, v.28, n.6, p.1382-1389, 1999.

NATIONAL RESEARCH COUNCIL - NRC. Nutrient requeriments of dairy cattle. 7.rev.ed. Washington, D.C: National Academy Press, 2001. 381p.

OWENS, F.N.; ZINN, R.A.; KIM, Y.K. Limits to starch digestion in the ruminant small intestine. Journal of Animal Science, v.63, n.5, p.1634-1648, 1986.

RIBEIRO, T.R.; PEREIRA, J.C.; OLIVEIRA, M.V.M. et al. Características da carcaça de bezerros holandeses para produção de vitelos recebendo dietas com diferentes níveis de concentrado. Revista Brasileira de Zootecnia, v.30, n.6, p.2154-2162, 2001 (supl.).

ROCHA, E.O.; FONTES, C.A.A.; PAULINO, M.F. et al. Ganho de peso, eficiência alimentar e características da carcaça de novilhos de origem leiteira. Revista Brasileira de Zootecnia, v.28, n.1, p.148-158, 1999.

RODRIGUES FILHO, M.; MANCIO, A.B.; LANA, R.P. et al. Desempenho e características de carcaça de novilhos de origem leiteira, alimentados com diferentes níveis de concentrado e de cama de frango. Revista Brasileira de Zootecnia, v.32, n.3, p.672-682, 2003.

SIGNORETTI, R.D.; SILVA, J.F.C.; VALADARES FILHO, S.C. et al. Crescimento, conversão alimentar e rendimento de carcaça de bezerros da raça holandesa alimentados com dietas contendo diferentes níveis de volumoso. Revista Brasileira de Zootecnia, v.28, n.1, p.185-194, 1999

SMITH, S.B.; CROUSE, J.D. Relative contributions of acetate, lactate and glucose to lipogenesis in bovine intramuscular and subcutaneous adipose tissue. Journal of Nutrition, v.114, n.4, p.153-162, 1984.

TANIGUCHI, K.; HUNTINGTON, G.B.; GLENN, B.P. Net nutrient flux by visceral tissues of beef steers given abomasal and ruminal infusions of casein and starch. Journal of Animal Science, v.73, n.1, p.236-249, 1995

VAZ, F.N.; RESTLE, J. Características de carcaça e da carne de novilhos hereford terminados em confinamento com diferentes fontes de volumoso. Revista Brasileira de Zootecnia, v.34, n.1, p.230-238, 2005.

VAZ, F.N.; RESTLE, J.; FEIJÓ, G.L.D. et al. Qualidade e composição química da carne de bovinos de corte inteiros ou castrados de diferentes grupos genéticos Charolês x Nelore. Revista Brasileira de Zootecnia, v.30, n.2, p.518-525, 2001.

WHEELER, T.L.; SHACKELFORD, S.D.; JOHNSON, L.P. et al. A comparison of Warner-Bratzler shear force assessment within and among institutions. Journal of Animal Science, v.75, n.9, p.2423-2432, 1997. 